\title{
Expression of various protection of telomeres 1 variants is associated with telomere length and radiosensitivity in colon and gastric adenocarcinoma cells in vitro
}

\author{
HAN LEI ${ }^{1}$, FU-XIANG ZHOU ${ }^{1-3}$, HUI XU ${ }^{1}$, XIAO-HONG PENG ${ }^{1}$, ZHI-GUO ZHANG $^{1}$, \\ WEN-BO WANG ${ }^{1}$, HAI-JUN YU ${ }^{1,2}$, CONG-HUA XIE ${ }^{1,2}$ and YUN-FENG ZHOU ${ }^{1-3}$ \\ ${ }^{1}$ Hubei Key Laboratory of Tumor Biological Behaviors; ${ }^{2}$ Department of Radiation and Medical Oncology, Zhongnan Hospital; \\ ${ }^{3}$ Hubei Clinical Cancer Study Center, Wuhan University, Wuhan, Hubei 430071, P.R. China
}

Received February 9, 2015; Accepted March 6, 2015

DOI: $10.3892 /$ br.2015.444

\begin{abstract}
Protection of telomeres 1 (POT1) is a telomere-binding protein, which binds to the single-stranded DNA extensions of telomeres and regulates telomere length. Different POT1 mRNA variants were examined and compared with telomere length and radiosensitivity in colon and gastric adenocarcinoma cells. POT1 production and telomere lengths were assessed using 10 human cancer cell lines by quantitative polymerase chain reaction (qPCR). POT1 mRNA levels, which were relatively stable, were significantly correlated with telomere length in gastric cancer cells and colon cancer cells, except for HT29 ( $\mathrm{P}<0.01)$. POT1 v5 indexes were closely associated with radiosensitivity in colon cancer cells and gastric cancer cells $(\mathrm{P}<0.05)$. In conclusion, POT1 may be a good marker for the examination of cell-specific telomere length and radiosensitivity.
\end{abstract}

\section{Introduction}

Telomeres are distinctive structures consisting of a specific DNA sequence (TTAGGG) and associated binding proteins that cap the ends of linear chromosomes (1). Telomeres enable cells to distinguish chromosomal ends from natural double-strand breaks in the genome (2). Due to the lack of telomerase or other mechanisms to maintain telomere length, telomeres undergo erosion following each cell cycle due to the replicating problem of the linear DNA telomere shortening to a critical length resulting in loss of telomere protection, which leads to cell cycle arrest and loss of cell viability (3). However, the human cancer cells have a relatively stable telomere length, which indicate its modulating role of telomeres in biology.

Correspondence to: Dr Fu-Xiang Zhou, Department of Radiation and Medical Oncology, Zhongnan Hospital, Wuhan University, 169 Donghu Road, Wuhan, Hubei 430071, P.R. China

E-mail: happyzhoufx@sina.com

Key words: protection of telomeres 1 variant, telomere length, radiosensitivity, chromosome protection
Our previous results indicated that there was a significant negative correlation of telomere length and radiosensitivity in the same tissue-derived cell lines, so telomeres may be used as a predictor of radiosensitivity (4). Additionally, the expression of protection of telomeres 1 (POT1) was significantly upregulated by 3.348-fold in the radioresisitant cancer cells compared to the radiosensitive cells through a cDNA microarray containing 14,000 human genes (5). All the above indicate that there may be a close association between POT1, telomere length and radiosensitivity in human cancer cells.

POT1, as a $3^{\prime}$ single-stranded overhang telomeric DNA-binding protein, has been identified in fission yeast and humans (6). A recent study indicated that each POT1 binds to one telomeric repeat and coats the entire single-stranded overhang of the telomere. In subsequent genetic and biochemical studies, the role of POT1 for telomere length maintenance and telomere capping has been identified. In addition to the full-length POT1 protein (also termed variant v1), at least four other isoforms (termed v2, v3, v4 and v5) are generated from the human POT1 gene due to RNA alternative splicing, in which the POT1 v1 and v5 variants have been widely studied $(7,8)$.

Regardless of the extensive studies conducted in the biological realm for POT1, the role of the POT1 level in radiosensitivity and telomere regulation in human cancer cells remains unclear. In the present study, the variant expression of POT1 v1 and v5 was investigated and its association with telomere length and radiosensitivity was explored in colon and gastric cancer cells.

\section{Materials and methods}

Cell culture. Five colon cancer cell lines (LOVO, colo205, HCT15, HCT116 and HT29) and five gastric cancer cell lines (AGS, SGC7901, MKN-45, MKN-28 and SNU-1) were obtained from the China Center for Type Culture Collection (Wuhan, China). All the cells were cultured in RPMI-1640 medium (Invitrogen Life Technologies, Carlsbad, CA, USA) supplemented with $10 \%$ fetal calf serum (GE Healthcare Life Sciences HyClone Laboratories, Logan, UT, USA) at $37^{\circ} \mathrm{C}$ in a humidified atmosphere containing $5 \% \mathrm{CO}_{2}$. 
Reverse transcription-quantitative polymerase chain reaction (RT-qPCR). Total RNA was isolated from cultured cells using the TRIzol ${ }^{\circledR}$ reagent (Invitrogen Life Technologies) and first-strand cDNA was synthesized using RevertAid first strand cDNA synthesis kit (MBI Fermentas, Vilnius, Lithuania) according to the manufacturer's instructions. To quantify full length POT1 mRNA levels, RT-qPCR was performed using $2 \mu \mathrm{l}$ cDNA with SYBR-Green I (Takara Bio, Inc., Shiga, Japan) in a total volume of $50 \mu \mathrm{l}$ with the primer 5'-CAGGAGCTG ACGTGGAAGAT-3' (forward) and 5'-ATGTATTGTTCC TTGTATAAGAAATGGTGC-3' (reverse). After enzyme activation for $10 \mathrm{~min}$ at $95^{\circ} \mathrm{C}, 40$ three-step cycles were performed (30 sec at $94^{\circ} \mathrm{C}, 30 \mathrm{sec}$ at $60^{\circ} \mathrm{C}$ and $20 \mathrm{sec}$ at $72^{\circ} \mathrm{C}$ ). RT-qPCR for POT1 v5 variant was performed as described above with primers 5'-CATCGGCTACAAAATCTG-3' and 5'-ACCAT TTTCTCTTGGTCTCAG-3.' $\beta$-actin expression was measured in all the samples as an endogenous control with primers. Threshold cycles $(\mathrm{Ct})$ of $\beta$-actin were used to calculate the $\mathrm{Ct}$ values, which were corrected for input cDNA. The average $\Delta \mathrm{Ct}$ value was used to calculate the $\Delta \Delta \mathrm{Ct}$ values. Relative mRNA expression was calculated with the formula: 2 EXP $(-\Delta \Delta \mathrm{Ct}) \times 100 \%$ and all the mRNA levels were indicated using the formula (target gene mRNA of sample/ $\beta$-actin of sample) $x 100$. All the samples were measured in triplicate in two separate experiments.

Measurement of telomere length.PCR reactions were performed using a method by Cawthon (9) by aliquoting $15 \mu \mathrm{l}$ of master mix into each reaction well of a 96-well plate compatible with the Mx3000P qPCR system (Agilent Technologies, Santa Clara, CA, USA) containing 20 ng DNA diluted in pure water, for a final volume of $25 \mu \mathrm{l} /$ reaction. Five concentrations of a reference DNA sample (the 'Standard DNA') were prepared by serial dilution and analyzed in duplicate in every 96-well plate, and these reactions provided the data for the generation of the standard curves used for relative quantitation. All the experimental DNA samples were assayed in triplicate. The final concentrations of reagents in the PCR reaction with SYBR-Green I (Takara Bio, Inc.) were $10 \mathrm{mmol} / 1$ Tris- $\mathrm{HCl}$ (pH 8.3), $50 \mathrm{mmol} / 1 \mathrm{KCl} 3 \mathrm{mmol} / \mathrm{l}$ $\mathrm{MgCl}_{2}, 0.2 \mathrm{mmol} / \mathrm{l}$ each deoxynucleotide, $1 \mathrm{mmol} / 1$ dithiothreitol and $1 \mathrm{M}$ betaine. Each $25 \mu \mathrm{l}$ reaction received $0.625 \mathrm{U}$ AmpliTaq Gold DNA polymerase (Applied Biosystems, Inc., Foster City, CA, USA). For multiplex RT-qPCR, the telomere primer pair telg and telc (final concentration of $900 \mathrm{nM}$ each), were combined either with the albumin primer pair albu and albd (final concentration of $900 \mathrm{nM}$ each), or with the $\beta$-globin primer pair hbgu and hbgd (final concentration of $500 \mathrm{nM}$ each) in the master mix. All the primer sequences and the rationale for their design are presented in the results section. The thermal cycling profile was stage $1: 15 \mathrm{~min}$ at $95^{\circ} \mathrm{C}$; stage 2 : 2 cycles of $15 \mathrm{sec}$ at $94^{\circ} \mathrm{C}$ and $15 \mathrm{sec}$ at $49^{\circ} \mathrm{C}$; and stage 3: 32 cycles of $15 \mathrm{sec}$ at $94^{\circ} \mathrm{C}, 10 \mathrm{sec}$ at $62^{\circ} \mathrm{C}, 15 \mathrm{sec}$ at $74^{\circ} \mathrm{C}$ with signal acquisition, $10 \mathrm{sec}$ at $84^{\circ} \mathrm{C}$ and $15 \mathrm{sec}$ at $88^{\circ} \mathrm{C}$ with signal acquisition. The $74^{\circ} \mathrm{C}$ reads provided the $\mathrm{Ct}$ values for the amplification of the telomere template, and the $88^{\circ} \mathrm{C}$ reads provided the $\mathrm{Ct}$ values for the amplification of the scg template. Following the completion of thermal cycling and raw data collection, two standard curves were generated for each plate; one for the telomere signal and one for the scg signal. The T/S ratio for an experimental DNA sample is T, which is the 'Standard DNA' that matches the experimental sample for copy number of the telomere template in nanograms, divided by $\mathrm{S}$, which is the 'Standard DNA' that matches the experimental sample for copy number of the scg in nanograms. As each experimental sample was assayed in triplicate, three T/S results were obtained for each sample; therefore, the final reported result for a sample in a given run is the average of the three T/S values. Average T/S is expected to be proportional to the average telomere length/cell. Samples with a T/S >1.0 have an average telomere length greater than that of the 'Standard DNA' samples, and those with a T/S $<1.0$ have an average telomere length shorter than that of the 'Standard DNA'.

Colony-forming assay. Cells were trypsinized at $37^{\circ} \mathrm{C}$ for 5-10 min and pipetted eight times to keep the clumped cells as a single cell suspension. The single cell suspension was adjusted and seeded into $25 \mathrm{~cm}^{2}$ flasks at various densities based on the results of the pre-experiments. Subsequently, the cells were left to settle overnight and were exposed to irradiation at room temperature, followed by immediate incubation at $37^{\circ} \mathrm{C}, 5 \% \mathrm{CO}_{2}$ for $14-20$ days. Following fixation and staining with $1 \% \mathrm{w} / \mathrm{v}$ crystal violet (Sigma-Aldrich, St. Louis, MO, USA) in dehydrated alcohol, colonies of $>50$ cells were scored. Surviving fractions (SF2) were evaluated relative to 0 Gy radiation-treated controls.

Statistical analysis. The statistical analyses were performed using SPSS 17.0 software (SPSS, Inc., Chicago, IL, USA) and assessed by the Mann-Whitney U test and Spearman's rank correlation test for equality of variances. $\mathrm{P}<0.05$ was considered to indicate a statistically significant difference.

\section{Results}

Expression levels of full length POT1 and POT1 v5 mRNA. Transcript levels of full length POT1 and POT1 v5 mRNA were determined by RT-qPCR in all 10 cancerous cell samples. In all these cell lines, full length POT1 mRNA levels with a mean value of $198 \pm 54$ ranged from 118 to 428 , and had a significant difference when compared to each other. The expression difference of full length POT1 mRNA levels in different tissue-derived cancer cells is shown in Fig. 1A. In addition, the POT1 v5 mRNA levels with a mean value of $18 \pm 5$ was in the range from 9 to 33 in all cancer cells. The expression of POT1 in different cancer cell types was relatively stable compared to the high variation of human telomerase reverse transcriptase. The expression difference of POT1 v5 mRNA levels in different tissue background cancer cells is shown in Fig. 1B.

Expression levels of POT1 mRNA and telomere length. There was an extremely weak correlation between the full length POT1 level and telomere length $\left(\mathrm{R}^{2}=0.284, \mathrm{P}<0.05\right)$. In particular, the linear correlation between them in colon cancer cells and gastric cancer cells was investigated. The mRNA levels of POT1 are positively correlated to telomere length in human gastric adenocarcinoma cell lines (Fig. 2A). However, a correlation in the colon cancer types was not found. The mRNA levels of POT1 are positively correlated to telomere length in human colon cell lines if HT29 is excluded from the group ( $\mathrm{P}<0.05$, Fig. $2 \mathrm{~B})$. No significant associations 

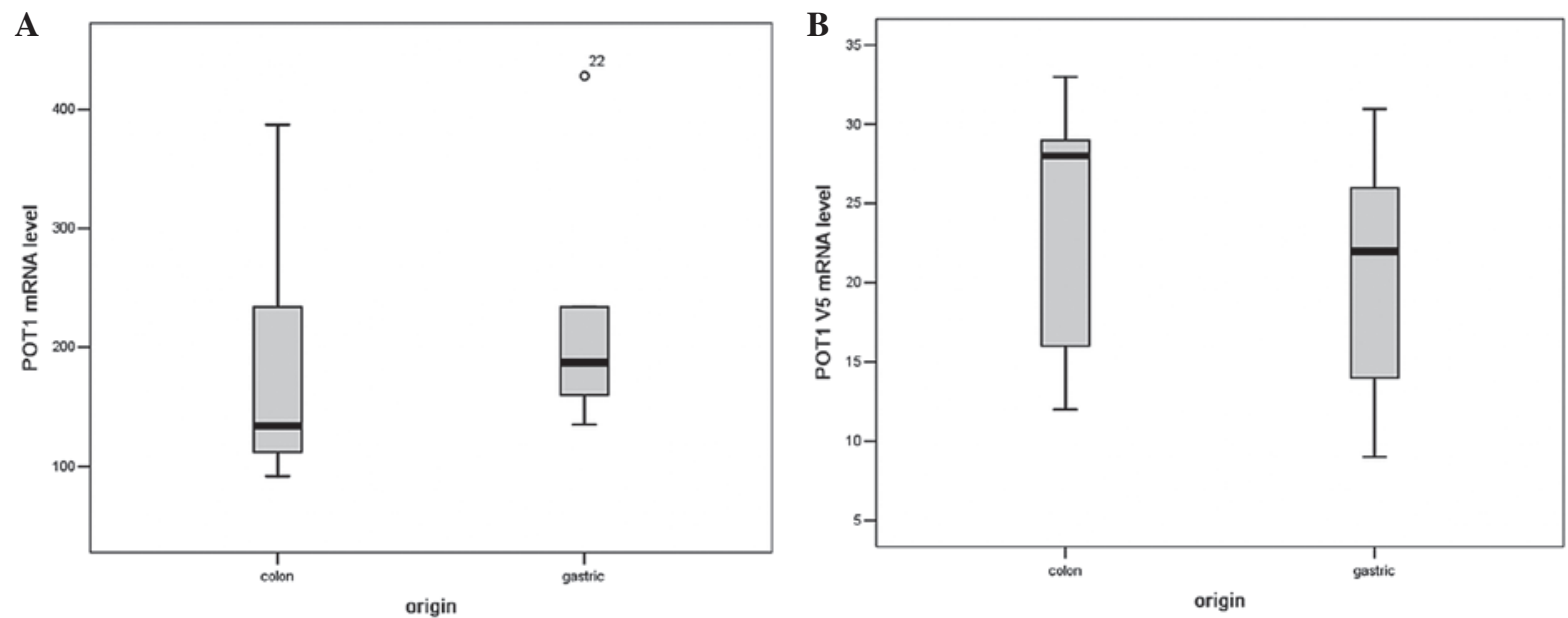

Figure 1. Expression levels of full length protection of telomeres 1 (POT1) and POT1 v5 mRNA. (A) Full length POT1 mRNA levels. Box plots (from the 25th to the 75th percentile with a line at the median) show the range of relative mRNA levels in various cell types. (B) Variation of $P O T 1$ v5 variant mRNA among cell types. Box plots (from the 25th to the 75th percentile with a line at the median) show the range of relative POT1 v5 variant mRNA levels in various cell types.

A

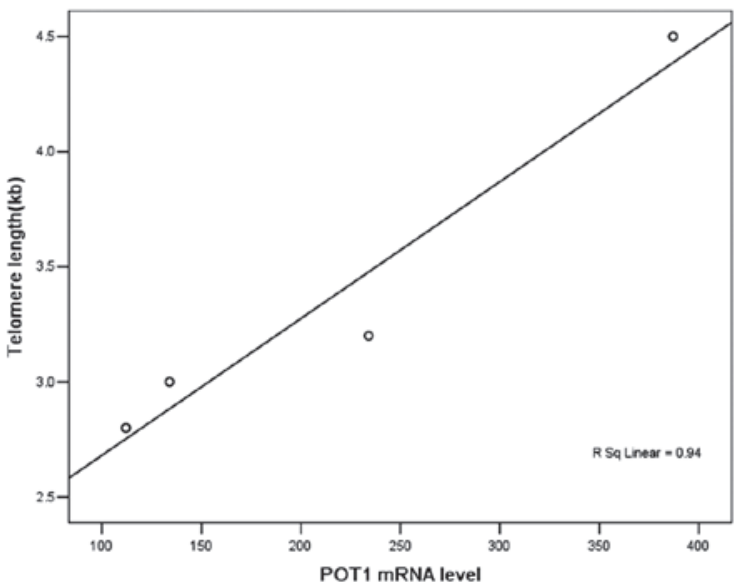

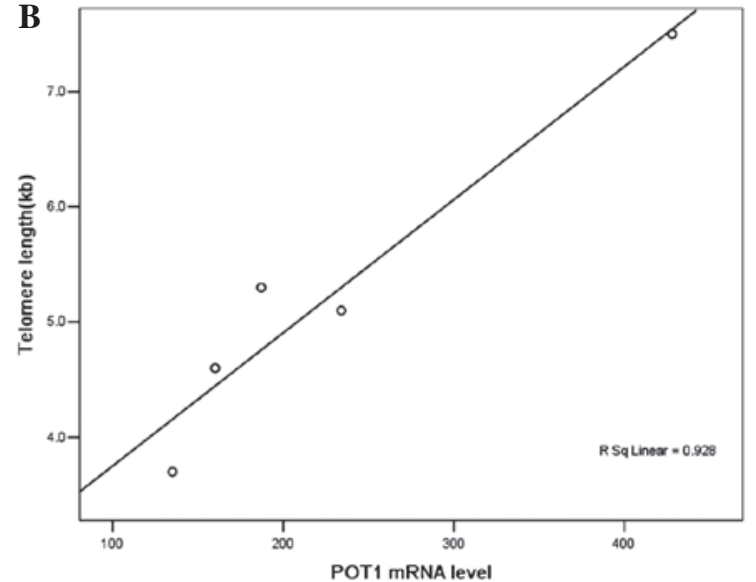

Figure 2. Expression levels of protection of telomeres 1 (POTI) mRNA and telomere length. (A) The mRNA levels of POT1 are positively correlated to telomere length in human gastric adenocarcinoma cell lines. (B) The mRNA levels of POT1 are positively correlated to telomere length in human colon cell lines if HT29 is excluded from the group.

were observed between telomere length and POT1 v5 mRNA levels.

Expression levels of POT1 mRNA levels and radiosensitivity. SF2 at 2 Gy was used as an index of clonogenic cellular radiosensitivity. The present results showed a correlation between radiosensitivity and POT1 mRNA levels in the 10 carcinoma cell lines in which linear regression analysis was used to establish a determination coefficient $\left(\mathrm{r}^{2}\right)$ of 0.054 for the association between POT1 mRNA levels and radiosensitivity (SF2) (P>0.05). Evidently, different radiosensitivities of cancer cell lines did not depend on the levels of full length POTI mRNA (Fig. 3A). Of note, there was a significant correlation between the POT1 v5 variant level and radiosensitivity in gastric cancer (Fig. 3B) and colon cancer cells (Fig. 3C). These results suggest that the POT1 v5 level is a critical factor in the regulation of radiosensitivity in colon and gastric adenocarcinoma cell lines. However, the correlation coefficient of only 0.633 (Fig. 3D) also suggests the presence of additional factors in the process of radiosensitivity regulation.

\section{Discussion}

Numerous findings suggested that human POT1 protein may function in telomere length regulation rather than in POT1 gene regulation, or more specifically the G-overhang (10-12). Previous studies have described the effects of perturbing POT1 function on telomere length in murine, galline and immortal human cells with constitutive telomerase expression (13-15). Certain data suggest that long telomere length appears to be a protective factor to the damaging effects of ionizing radiation (16). This finding solved a major challenge in cell biology: The limited replicative life span of non-transformed human cells known as the 'Hayflick limit'. These results would verify the well-known association between telomere and genome stability. Short telomeres are likely to interfere with the efficient repair of double strand breaks in the genome, resulting in a higher sensitivity to ionizing radiation (17). Increasing evidence suggests that POT1 functions in telomere overhang protection, telomeres' DNA damage signaling and cell cycle progression $(18,19)$. 
A

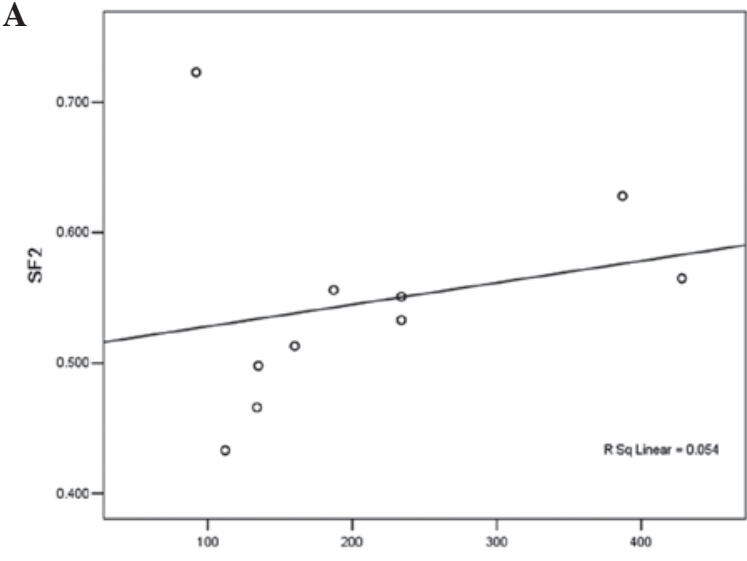

C

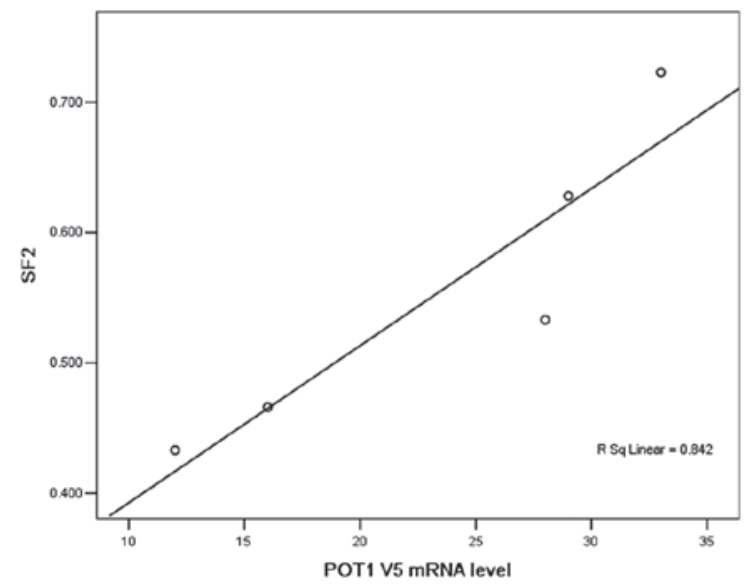

B

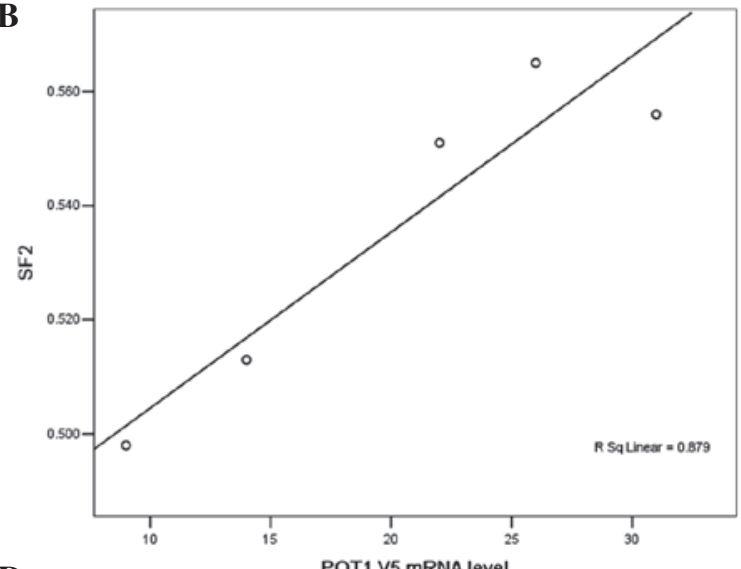

D

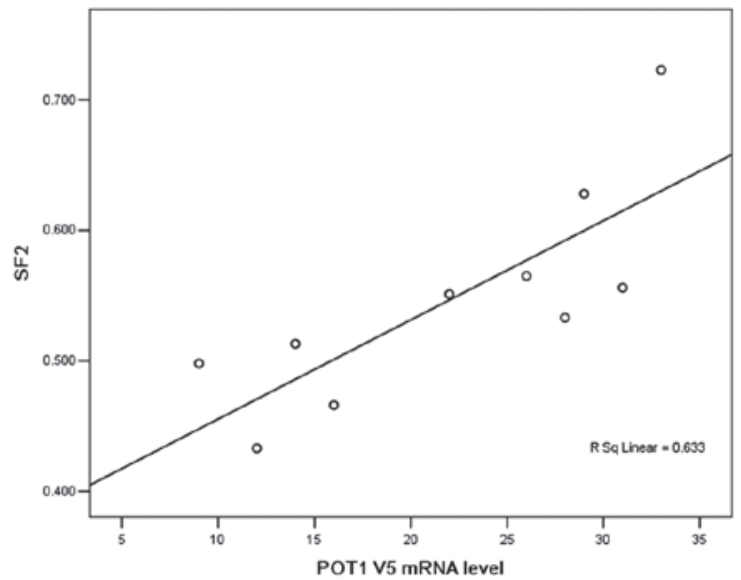

Figure 3. Expression levels of protection of telomeres 1 (POT1) mRNA levels and radiosensitivity. (A) There is no significant correlation between full length POT1 mRNA levels and surviving fraction (SF2) in human gastric and colon adenocarcinoma cell lines. (B) There is a significant correlation between POT1 v5 mRNA levels and SF2 in human gastric adenocarcinoma cell lines. (C) There is a significant correlation between POT1 v5 mRNA levels and SF2 in human colon adenocarcinoma cell lines. (D) There is a significant correlation between POT1 v5 mRNA levels and SF2 in human gastric and colon adenocarcinoma cell lines.

Other data indicate that POT1 is essential to maintain the normal structure at telomeric single-stranded overhangs, protect against apoptosis and prevent chromosomal instability and senescence (20-22). In the two cases, POT1 was found to be essential for the prevention of activating a catastrophic DNA damage response (23). The radiosensitivity of cancer cells is known to depend on the DNA damage response and its consequence. In the present study, POT1 mRNA levels (POTl v1 and v5 variant) were inversely associated with the radiosensitivity in gastric cancer cells. Adequate telomere length, telomerase activity and T-loop formation play important roles in maintenance of telomere function and when only one mechanistic factor is compromised, such as lack of functional telomerase or telomere shortening, the other components of the capping system can compensate.

Telomere dysfunction appears to increase the frequency of genetically initiated DNA damage response (24). Telomeres eliciting a DNA damage response (DDR) were still able to repress end-to-end fusions through the retention of POT1 at the dysfunctional chromosome end (25). In cell extracts, POT1 and its binding partner, tripeptidyl peptidase I, are required to prevent non-homologous end joining-dependent telemetric DNA fusions, suggesting that these proteins directly inhibit the ligation reaction (26). Recent studies have uncovered an apparent paradox: Several proteins involved in DNA damage processing and checkpoint responses are recruited to telomeres in every cell cycle and are required for end protection, although DNA repair is prevented (27). In this setting, telomere dysfunction resulting in a DDR with defiant POTI leads to end-to-end chromosome fusions and indicate more radiosensitive to ionizing radiation.

The present study demonstrates that POTI mRNA levels modulate telomere length or radiosensitivity in vitro in colon and gastric adenocarcinoma cancer cells, and these findings confirm the conclusion that the POTl v1 or v5 variant mRNA level can act as a biomarker of radiosensitivity of cancer cells upon ionizing radiation. The reduced $P O T 1$ expression levels are assumed to reflect the telomere dysfunction and may serve as a possible predictor of individual radiosensitivity and carcinogen. Due to the lack of a rapid and high-throughput biological measurement to quantify POTI mRNA levels, this assumption remains to be demonstrated. More in vivo studies in human cancer cells are also required to reinforce this assumption.

\section{Acknowledgements}

The present study was supported by the National Natural Science Foundation of China (grant no. 30770643). 


\section{References}

1. de Lange T: Shelterin: The protein complex that shapes and safeguards human telomeres. Genes Dev 19: 2100-2110, 2005.

2. Stewart SA, Ben-Porath I, Carey VJ, O'Connor BF, Hahn WC and Weinberg RA: Erosion of the telomeric single-strand overhang at replicative senescence. Nat Genet 33: 492-496, 2003.

3. Maser RS and DePinho RA: Connecting chromosomes, crisis, and cancer. Science 297: 565-569, 2002.

4. Tang T, Zhou FX, Lei H, Yu HJ, Xie CH, Zhou YF and Liu SQ Increased expression of telomere-related proteins correlates with resistance to radiation in human laryngeal cancer cell lines. Oncol Rep 21: 1505-1509, 2009.

5. Zhou FX, Xiong J, Luo ZG, Dai J, Yu HJ, Liao ZK, Lei H, Xie CH and Zhou YF: cDNA expression analysis of a human radiosensitive-radioresistant cell line model identifies telomere function as a hallmark of radioresistance. Radiat Res 174: 550-557, 2010.

6. Lei M, Podell ER and Cech TR: Structure of human POT1 bound to telomeric single-stranded DNA provides a model for chromosome end-protection. Nat Struct Mol Biol 11: 1223-1229, 2004.

7. Colgin LM, Baran K, Baumann P, Cech TR and Reddel RR: Human POT1 facilitates telomere elongation by telomerase. Curr Biol 13: 942-946, 2003.

8. Wu L, Multani AS, He H, Cosme-Blanco W, Deng Y, Deng JM, Bachilo O, Pathak S, Tahara H, Bailey SM, et al: Pot1 deficiency initiates DNA damage checkpoint activation and aberrant homologous recombination at telomeres. Cell 126: 49-62, 2006.

9. Cawthon RM: Telomere length measurement by a novel monochrome multiplex quantitative PCR method. Nucleic Acid Res 37: e21, 2009.

10. Opresko PL, Mason PA, Podell ER, Lei M, Hickson ID, Cech TR and Bohr VA: POT1 stimulates RecQ helicases WRN and BLM to unwind telomeric DNA substrates. J Biol Chem 280: 32069-32080, 2005.

11. Baumann P, Podell E and Cech TR: Human Pot1 (protection of telomeres) protein: Cytolocalization, gene structure, and alternative splicing. Mol Cell Biol 22: 8079-8087, 2002.

12. Sedelnikova OA, Horikawa I, Zimonjic DB, Popescu NC, Bonner WM and Barrett JC: Senescing human cells and ageing mice accumulate DNA lesions with unrepairable double-strand breaks. Nat Cell Biol 6: 168-170, 2004.

13. Michishita E, Park JY, Burneskis JM, Barrett JC and Horikawa I: Evolutionarily conserved and nonconserved cellular localizations and functions of human SIRT proteins. Mol Biol Cell 16 4623-4635, 2005.

14. Baumann P and Cech TR: Pot1, the putative telomere end-binding protein in fission yeast and humans. Science 292: 1171-1175, 2001.
15. Churikov D, Wei C and Price CM: Vertebrate POT1 restricts G-overhang length and prevents activation of a telomeric DNA damage checkpoint but is dispensable for overhang protection. Mol Cell Biol 26: 6971-6982, 2006.

16. Rangarajan A and Weinberg RA: Opinion: Comparative biology of mouse versus human cells: modelling human cancer in mice. Nat Rev Cancer 3: 952-959, 2003.

17. Wu X, Amos CI, Zhu Y, Zhao H, Grossman BH, Shay JW, Luo S, Hong WK and Spitz MR: Telomere dysfunction: A potential cancer predisposition factor. J Natl Cancer Inst 95: 1211-1218, 2003.

18. Widmann TA, Herrmann M, Taha N, König J and Pfreundschuh M: Short telomeres in aggressive non-Hodgkin's lymphoma as a risk factor in lymphomagenesis. Exp Hematol 35: 939-946, 2007.

19. Ohali A, Avigad S, Ash S, Goshen Y, Luria D, Feinmesser M, Zaizov R and Yaniv I: Telomere length is a prognostic factor in neuroblastoma. Cancer 107: 1391-1399, 2006.

20. Hakin-Smith V, Jellinek DA, Levy D, Carroll T, Teo M, Timperley WR, McKay MJ, Reddel RR and Royds JA: Alternative lengthening of telomeres and survival in patients with glioblastoma multiforme. Lancet 361: 836-838, 2003.

21. Avigad S, Naumov I, Ohali A, Jeison M, Berco GH, Mardoukh J, Stark B, Ash S, Cohen IJ, Meller I, et al: Short telomeres: A novel potential predictor of relapse in Ewing sarcoma. Clin Cancer Res 13: 5777-5783, 2007.

22. Shen J, Terry MB, Gurvich I, Liao Y, Senie RT and Santella RM: Short telomere length and breast cancer risk: A study in sister sets. Cancer Res 67: 5538-5544, 2007.

23. Halaschek-Wiener J, Vulto I, Fornika D, Collins J, Connors JM, Le ND, Lansdorp PM and Brooks-Wilson A: Reduced telomere length variation in healthy oldest old. Mech Ageing Dev 129: 638-641, 2008

24. Gertler R, Rosenberg R, Stricker D, Friederichs J, Hoos A, Werner M, Ulm K, Holzmann B, Nekarda H and Siewert JR Telomere length and human telomerase reverse transcriptase expression as markers for progression and prognosis of colorectal carcinoma. J Clin Oncol 22: 1807-1814, 2004.

25. Hackett JA and Greider CW: Balancing instability: Dual roles for telomerase and telomere dysfunction in tumorigenesis. Oncogene 21: 619-626, 2002

26. Greider CW: Telomere length regulation. Annu Rev Biochem 65: 337-365, 1996.

27. Doksani Y and de Lange T: The role of double-strand break repair pathways at functional and dysfunctional telomeres. Cold Spring Harb Perspect Biol 6: a016576, 2014. 